\title{
ANALISIS MINAT BELAJAR SELAMA PANDEMI COVID-19 DI SMP NEGERI 1 BARUS
}

\author{
Oleh : \\ Suhetni Asmarita Situmorang'), Mhd. Nau Ritonga ${ }^{2)}$, Eva Yanti Siregar ${ }^{3)}$ \\ Fakultas MIPA, Institut Pendidikan Tapanuli Selatan \\ asmaritasuhetni@gmail.com
}

\begin{abstract}
The background of this research is Covid-19 pandemic early 2020 that caused teaching learning process changed from offline become online. This case caused students' activeness in learning is reduced. The aim of this study is to know students' learning interest in Covid-19 pandemic period at seventh grade students of SMP Negeri 1 Barus. Questionnaire was used in collecting the data and subject consist of 26 students. The result of the research shows $34.61 \%$ is enough category (9 students), 11.24\% is good category (3 students), $3.85 \%$ is very good category (1 student).
\end{abstract}

\section{Keywords: learning interest, mathematic learning, Covid-19}

\section{Abstrak}

Latar belakang penelitian ini adalah pandemi Covid-19 pada awal tahun 2020 yang menyebabkan proses belajar mengajar berubah dari offline menjadi online. Hal ini menyebabkan keaktifan siswa dalam belajar berkurang. Tujuan penelitian ini adalah untuk mengetahui minat belajar siswa pada periode pandemi Covid-19 pada siswa kelas VII SMP Negeri 1 Barus. Angket digunakan dalam pengumpulan data dan subjek terdiri dari 26 siswa. Hasil penelitian menunjukkan 34,61\% kategori cukup (9 siswa), 11,24\% kategori baik (3 siswa), 3,85\% kategori sangat baik (1 siswa).

\section{Kata kunci: minat belajar, pembelajaran matematika, Covid-19}

\section{PENDAHULUAN}

Pada awal tahun 2020 dunia tengah diresahkan dengan adanya wabah Corona Virus Disesase (Covid-19). Corona Virus adalah keluarga besar virus yang menyebabkan penyakit mulai dari gejala ringan sampai berat. Corona Virus Disesase (Covid-19) adalah penyakit jenis baru yang belum pernah diidentifikasi sebelumnya pada manusia. Akibat adanya virus tersebut, situasi membuat kehidupan menjadi terkendala termasuk aspek pendidikan karena virus tersebut dengan cepat menyebar atau menular dari manusia ke manusia melalui sentuhan ataupun saat bersin maupun batuk. Sehingga, segala aktivitas yang dilakukan diluar rumah khususnya terhadap siswa yang dilakukan tatap muka harus dihentikan dimana situasi saat ini menuntut siswa untuk waspada dengan lingkungan kehidupan sehari-hari.

Melihat kondisi saat ini keaktifan siswa dalam belajar berkurang yang disebabkan adanya pandemi covid-19, yang membuat proses belajar mengajar yang umumnya di laksanakan secara tatap muka di kelas menjadi proses pembelajaran di rumah. Hal ini, dilakukan demi menjaga keselamatan berbagai pihak termasuk guru dan siswa. Dalam menumbuhkan minat siswa dalam belajar matematika dapat dilakukan dengan berbagai cara. Misalnya saat pembelajaran selama pendemi covid-19 guru menggunakan metode dan media pembelajaran agar minat siswa dapat bertambah didalam belajar meningkat sehingga siswa akan lebih mudah mencapai keberhasilan dalam belajar.

Orang tua siswa dituntut untuk mendampingi siswa dalam belajar dirumah namun sebagian orang tua tidak mampu karena mereka tidak memiliki latar belakang pendidikan yang cukup (mereka kurang memahami pelajaran), sehingga siswa malas mengerjakan tugas. Disamping itu, tidak semua siswa memiliki alat perangkat pembelajaran yang memadai sehingga minat belajar siswa menurun. Siswa lebih banyak menghabiskan waktu dengan bermain dan menonton televisi dan tidak mengerjakan tugas yang diberikan guru. Oleh karena itu peneliti tertarik mengangkat judul analisis minat belajar siswa selama pandemi covid-19 di smp negeri 1 barus"

Hakim dalam Naeklan 2020:15) mengatakan bahwa "Minat merupakan perhatian yang bersifat khusus, siswa yang menaruh minat pada suatu mata pelajaran, perhatiannya akan tinggi dan minatnya berfungsi sebagai pendorong kuat untuk terlibat secara aktif dalam kegiatan belajar mengajar". Menurut Slameto (Naeklan, 2020:15) mengatakan bahwa "Minat adalah suatu lebih rasa suka dan rasa kaitan pada suatu hal atau aktivitas, tanpa ada yang menyuruh”. Menurut Tatan dan Teti (Lestari 2015:117) 
mengatakan bahwa "Belajar adalah selalu melibatkan perubahan dalam diri individu seperti kematangan berpikir, berperilaku maupun kedewasaan dalam menentukan keputusan dan pilihan”. Menurut Sutikno (Astuti 2015:69) mengatakan bahwa "Belajar adalah proses orang memperoleh berbagai kecakapan dan sikap".

Berdasarkan beberapa pendapat ahli diatas penulis menyimpulkan bahwa belajar adalah sebagai suatu usaha yang dilakukan oleh seseorang untuk tujuan perubahan tingkah laku melalui interaksi dengan lingkungan. Belajar itu adalah proses usaha yang dilakukan oleh seseorang itu memperoleh suatu perubahan tingkah laku yang baru secara keseluruhan sebagai hasil pengalamannya dalam interaksinya dengan lingkungan". Menurut Dalyono (Rachmawati dan Sojanah 2019:219) mengatakan bahwa "Minat belajar yang besar cenderung menghasilkan prestasi yang tinggi, sebaliknya minat belajar yang kurang akan menghasilkan prestasi yang rendah".

Minat belajar adalah perasaan senang, suka dan perhatian terhadap usaha untuk mendapat ilmu pengetahuan.Menurut Hansen (Fauziah dkk 2017:49) mengatakan bahwa "Minat belajar siswa erat hubungannya dengan kepribadian, motivasi, ekspresi dan konsep diri atau identifikasi, faktor keturunan dan pengaruh eksternal atau lingkungan".

Berdasarkan beberapa pendapat ahli diatas penulis menyimpulkan bahwa minat belajar merupakan dorongan batin yang tumbuh dari seseorang siswa untuk meningkatkan kebiasaan belajar. Minat belajar akan tumbuh dari seseorang siswa memiliki keinginan untuk meraih nilai terbaik, atau ingin memenangkan persaingan dalam belajar dengan siswa lainnya.

Menurut Slameto dalam Nurhasanah dan Sobandi (2016:130-131), diantaranya yaitu: ketertarikan untuk belajar, perhatian dalam belajar, motivasi belajar dan pengetahuan.

1. Ketertarikan untuk belajar

Ketertarikan untuk belajar diartikan apabila seseorang yang berminat terhadap suatu pelajaran maka ia akan memiliki perasaan ketertarikan terhadap pelajaran tersebut. Siswa akan rajin dan terus memiliki perasaan ketertarikan terhadap pelajaran tersebut, siswa akan mengikuti pelajaran dengan penuh antusian tanpa ada beban pada dirinya.

2. Perhatian dalam belajar

Perhatian merupakan konsentrasi atau aktivitas jiwa seseorang terhadap pengamatan, pengertian ataupun yang lainnya dengan mengesampingkan hal lain dari pada itu. Jadi, siswa akan mempunyai perhatian dalam belajar, jika jiwa dan pikirannya terfokus dengan apa yang siswa pelajari.

3. Motivasi belajar

Motivasi merupakan suatu usaha atau pendorong yangdilakukan secara sadar untuk melakukan tindakan belajar dan mewujudkan perilaku yang terarah demi pencapaian tujuan yang diharapkan dalam situasi interaksi belajar.

4. Pengetahuan

Pengertian diartikan bahwa jika seseorang yang berminat terhadap suatu pelajaran maka akan mempunyai pengetahuan yang luas tentang pelajaran tersebut serta bagaimana manfaat belajar dalam kehidupan sehari-hari.

Berdasarkan beberapa pendapat ahli diatas peneliti menggunakan 4 indikator, yaitu ketertarikan dalam belajar, perhatian dalam belajar, motivasi belajar, dan pengetahuan. Minat belajar merupakan faktor pendorong siswa dalam belajar yang didasari atas ketertarikan atau rasa senang dan keinginan siswa untuk belajar.

\section{HAKIKAT PANDEMI COVID-19}

Menurut Nurkholis (2020:41) mengatakan bahwa "Virus corona adalah penyakit yang menular yang disebabkan oleh SARS-CoV-2 penyakit ini disebut coronavirus dimana penyakit ini telah menjadi pandemi ditahun 2019-2020". Menurut Yunus (2020:228) mengatakan: "Corona virus adalah sekelompok virus yang dapat menyebabkan penyakit manusia yang menyebabkan infeksi saluran pernapasan yang umumnya ringan, seperti pilek, meskipun beberapa bentuk penyakit seperti; SARS, MERS, dan Covid-19 sifatnya lebih mematikan". Menurut Adib (2020:29) mengatakan "Covid 19 adalah merupkan penyakit yang menular yang disebabkan oleh saluran pernapasan akut corona virus 2 (Severe Acute Respiratory Syndrome Corona Virus 2 atau SARS-CoV-2). Virus ini merupakan keluarga besar corona virus yang apat menyeranng hewan.Ketika menyerang manusia, corona virus menyebabkan penyakit infeksi saluran pernapasan, seperti plu, MERS (Middle East Respiratory Syndrome), dan SARS (Severe Acute Respiratory Syndrome). Covid 19 sendiri merupakan corona virus jenis baru yang ditemukan di wuhan Cina pada 2019”. Menurut Fitriyani (2020:166) mengatakan “Corona virus Disease (Covid-19) adalah 
penyakit jenis baru yang belum pernah diidentifikasi sebelumnya pada manusia, pada tanggal 30 Januari 2020 WHO telah menetapkan sebagai kedaruratan kesehatan masyarakat yang meresahkan dunia”.

Berdasarkan pendapat diatas maka peneliti menyimpulka corona virus adalah penyakit jenis baru yang menyerang saluran pernapasan pada manusia yang berasal dari Wuhan China pada akhir 2019.

Pandemi Covid-19 menjadi persoalan yang dihadapi oleh dunia, hal tersebut juga dirasakan dampaknya dalam sektor pendidikan yang menyebabkan penurunan kualitas belajar pada peserta didik, masa darurat pendemi ini mengharuskan sistem pembelajaran daring agar prose pembelajaran tetap berlangsung.Pandemi adalah skala penyebaran penyakit yang terjadi secara global diseluruh dunia. Pandemi ini yang terjadi pula di Indonesia membuat banyak pihak berupaya ikut berperan serta dalam mengatasi.

Menurut Nurkholis (2020:41) "Infeksi menyebar dari satu orang ke orang lain melalui percikan (droplet) dari saluran pernapasan yang sering dihasilkan saat batuk dan bersin. Selain itu, dengan adaya virus Covid-19 pemerintah membuat beberapa kebijakan untuk menghentikan penyebaran wabah ini, seperti melakukan lockdown di daerah yang sudah termasuk ke dalam zona merah penyebaran virus secara kontak fisik". Menurut Nurkholis (2020:41) adapun sebagian besar cara mengantisipasi gejala ini dengan langkah-langkah yaitu sebagai berikut:

1. Sering-sering mencuci tangan dengan bersih

2. Tutup mulut atau hidung ketika bersin atau batuk menggunakan situ atau siku yang di lipat

3. Menggunakan masker sesuai standar masker

4. Melakukan sosial distancing dengan jarak minimal 1 meter serta hindari keramaian dengan berbagai kontak fisik

5. Tidak berpergian keluar kecuali saat darurat

6. Jangan menyentuh mata, hidung, mulut dengan tangan yang kotor.

Salah satu dampak pandemi Corona Virus 2019-2020 ialah terhadap pendidikan diseluruh dunia, yang mengarah kepada penutupan luas sekolah dan lain-lain. Penutupan sekolah adalah respons terhadap pandemi Covid-19 yang mempengaruhi akses ke pendidikan, karena penutupan sementara atau tidak terbatas termasuk di Indonesia sebagai langkah upaya memutus rantai penyebaran Covid-19

\section{METODE PENELITIAN}

Metode penelitian merupakan suatu cara yang digunakan dalam penelitian untuk mengumpulkan data penelitian. Sugiyono (2018:2) mengatakan "Metode penelitian pada dasarnya merupakan cara ilmiah untuk mendapatkan data dengan tujuan dan kegunaan tertentu”. Menurut Sugiyono (2018:14) mengatakan bahwa "Metode penelitian kuantatif dapat diartikan sebagai metode penelitian yang berlandaskan pada filsafat positiveme, digunakan untuk meneliti pada populasi atau sampel tertentu, teknik pengampilan sampel pada umumnya dilakukan secara random, pengumpulan data menggunakan instrumen penelitian analisis data bersifat kuantitatif/statistik dengan tujuan untuk menguji hipotesis yang telah ditetapkan". Metode penelitian dalam penelitian ini menggunakan metode penelitian kuantitatif. Jenis-jenis metode penelitian menurut Rangkuti (2014:16) dikelompokkan menjadi:

1. Penelitian Deskriptif adalah penelitian yang dilakukan untuk mengetahui nilai variabel bebas, baik satu variabel atai lebih (independent) tanpa membuat perbandingan, atau menghubungkan variabel yang satu dengan yang lain.

2. Penelitian Komparatif merupakan suatu penelitian yang bersifat membandingkan sesuatu.

3. Penelitian Asosiatif adalah penelitian yang bertujuan untuk mengetahui hubungan dua variabel atau lebih.

\section{Populasi dan Sampel Penelitian}

\section{Populasi Penelitian}

Populasi merupakan seluruh objek yang akan dijadikan sebagai sumber untuk memperoleh data yang dibutuhkan. Menurut Sugiyono (2018:117) mengatakan bahwa "Populasi adalah wilayah generalisasi yang terdiri atas: objek/subyek yang mempunyai kualitas dan karakteristik tertentu yang ditetapkan oleh peneliti untuk dipelajari dan kemudian ditarik kesimpulannya". Objek yang akan diteliti oleh peneliti. Maka yang menjadi populasi dalam penelitian ini adalah siswa kelas VII SMP Negeri 1 Barus.

\section{Sampel penelitian}


Sampel merupakan bagian dari populasi yang menjadi objek dalam penelitian. Menurut Sugiyono (2018:118) mengatakan bahwa "Sampel adalah bagian dari jumlah dan karakteristik yang dimiliki oleh populasi tersebut". Adapun menurut Rangkuti (2014:51) mengatakan bahwa "Sampel adalah sebagian dari objek yang akan diteliti yang dipilih sedemikian rupa sehingga mewakili keseluruhan objek (populasi) yang akan diteliti”. Pengambilan sampel ini dilakukan dengan cara diundi dimana seluruh objek memiliki kesempatan yang sama untuk dipilih sebagai sampel dan sifat populasinya harus homogen. Penulis mengambil sampel sebayak 1 kelas untuk mewakili seluruh siswa kelas VII yaitu, kelas VII B sebanyak 26 orang.

\section{Instrumen Penelitian}

Menurut Rangkuti (2014:63) mengatakan bahwa "Instrumen pengumpulan data adalah alat bantu yang dipilih dan digunakan oleh penelliti dalam kegiatannya mengumpulkan agar kegiatan tersebut menjadi sistematis dan dipermudah olehnya".

Menurut Sugiyono (2014:178) mengatakan bahwa "Instrumen penelitian adalah suatu alat yang digunakan mengukur penomena alam maupun sosial yang diamati”. Berdasarkan beberapa pendapat ahli diatas peneliti menyimpulkan bahwa instrumen penelitian adalah alat bantu yang dipilih dan digunakan untuk mengukur informasi dan data oleh peneliti dalam proses pengumpulan data dipenelitian dilapangan

\section{Teknik Pengumpulan Data}

Teknik pengumpulan data merupakan langkah atau cara mengumpulan data dengan tujuan mendapatkan data yang lebih valid. Menurut Rangkuti (2014:120) berpendapat bahwa "Teknik pengumpulan data merupakan langkah yang paling utama dalam penelitian, karena tujuan utama dari penelitian adalah untuk mendapatkan data". Menurut Arikunto (2006:150-158) mengatakan teknik pengumpulan data dapat dilakukan dengan tes, angket atau kuesioner (questionnaires), interview (interview), observasi, dokumentasi. Maka dalam penelitian ini penulis menggunakan teknik pengumpulan data berupa angket.

\section{Angket}

Angket dapat berupa pertanyaan/pernyataan tertutup atau terbuka, dapat diberikan kepada responden secara langsung atau dikirim melalui pos, atau internet. Angket adalah teknik pengumpulan data dengan cara mengajukan pernyataan-pernyataan yang tertulis.

\section{Tabel 1}

Kisi-kisi Indikator Minat Belajar Siswa Dalam Pembelajaran Kelas VII Selama Pandemi Covid-19

\begin{tabular}{llcc}
\hline No & \multicolumn{1}{c}{ Indikator } & $\begin{array}{c}\text { Item } \\
\text { Pernyataan }\end{array}$ & $\begin{array}{c}\text { Banyak } \\
\text { Peryataan }\end{array}$ \\
\hline 1 & Ketertarikan untuk belajar & $1,2,3,4$ & 4 \\
\hline 2 & Perhatian dalam belajar & $5,6,7,8$ & 4 \\
\hline 3 & Motivasi belajar & $9,10,11$ & 3 \\
\hline 4 & Pengetahuan & $12,13,14,15$ & 4 \\
\hline \multicolumn{2}{r}{ Jumlah } & $\mathbf{1 5}$ \\
\hline
\end{tabular}

\section{Teknik Analisis Data}

Analisis data merupakan proses yang pencarian dan penyusunan secara sitematik transkrip interiew, catatan lapangan dan material lainnya yang diakumulasikan untuk meningkatkan pemahaman penelti terhadap apa yang ditelitinya. Menurut Sugiyono (2018:335) mengatakan "Analisis data adalah proses mencari dan menyususn secara sistematis data yang diperoleh dari wawancara, catatan lapangan, dan dokumentasi dengan cara mengorganisasikan data kedalam kategori, menjabarkan kedalam unit-unit, melakukan sintesa,menyusun kedalam pola, memilih man ayang penting dan yang akan dipelajari, dan membuat kesimpulan sehingga mudah dipahami oleh diri sendiri maupun orang lain”.

Berdasarkan beberapa pendapat ahli diatas peneliti menyimpulkan analisis data adalah proses mencari dan menyusun urutan data secara sitematis dengan cara mengorganisasikan data kedalam kategori, menjabarkan, melakukan sintesa, menyusun kedalam pola, memilih mana yang penting, dan membuat kesimpulan sehingga mudah dipahami oleh diri sendiri maupun orang lain. Adapun teknik analisis yang digunakan yaitu analisis data hasil angket.

Berbagai skala sikap yang dapat digunakan untuk penelitian pendidikan, menurut Sugiyono (2014:132-139), yaitu:

1. Skala likert digunakan untuk mengukur sikap, pendapat, dan persepsi seseorang atau sekelompok orang tentang fenomena sosial, yaitu "sangat baik", "baik", "cukup", "kurang", "sangat kurang", "sering", "pernah" dan "tidak pernah". 
2. Skala Guttman yaitu skala pengukuran yang akan mendapat jawaban yang tegas, yaitu "ya-tidak", "benar-salah", "pernah-tidak pernah", "positif-negatif ", dan lainlain.

3. Semantic Defferensial digunakan untuk mengukur sikap, hanya untuk pilihan ganda maupun cheklist, tetapi tersusun dalam satu garis kontinum.

4. Rating Scale yaitu data mentah yang diperoleh berupa angka kemudian ditafsirkan dalam pengertian kualitatif.

Berdasarkan uraian diatas maka peneliti menggunakan menggunakan skala guttman dalam penelitian ini, yaitu dengan jawaban "Ya" dan "Tidak Pernah", dengan perhitungan ya $=1$ dan tidak = 0 . Instrumen penelitian yang menggunakan skala guttman dapat dibuat dalam bentuk cheklis.

$$
\text { Nilai akhir }=\frac{\text { Jumlah Skor yang diperoleh }}{\text { Jumlah Skor Maksimal }} \text { X 100\% }
$$

Persentase kemudian dikategorikan dengan klasifikasi berdasarkan perhitungan rumus interval kelas dalam Ridwan dan Akdon (2007: 36), sebagai berikut:

Tabel 2

\begin{tabular}{cc}
\multicolumn{2}{c}{$\begin{array}{c}\text { Klasifikasi Hasil Angket Minat Belajar Siswa Selama Pendemi } \\
\text { Covid-19 Di SMP Negeri 1 Barus }\end{array}$} \\
\hline $\begin{array}{c}\text { Persentase Skor Yang } \\
\text { Diperoleh }\end{array}$ & Kategori \\
\hline $0-19,99 \%$ & Kurang \\
\hline $20,99 \%-39,99 \%$ & Cukup \\
\hline $40,99 \%-59,99 \%$ & Sedang \\
\hline $60,99 \%-79,99 \%$ & Baik \\
\hline $80,99 \%-100 \%$ & Sangat Baik \\
\hline
\end{tabular}

\section{HASIL DAN PEMBAHASAN}

\section{Gambaran Umum Lokasi Penelitian}

Penelitian ini dilakukan di SMP Negeri 1 Barus yang beralamat Jln. Jenderal Sudirman No. 14 Padang Masiang Kecamatan Barus Kabupaten Barus, kode pos 22564, akreditasi B, yang dipimpin oleh Ratna Dewi Hasibuan, M.Pd selaku kepala sekolah, operator sekolah yaitu Ronny Arby Rambe. Jumlah guru yang mengajar sebanyak 31 guru, jumlah siswa sebanyak 396 terdiri dari 210 siswa laki-laki dan 186 siswa perempuan. Kurikulum yang digunakan yaitu K13. Luas tanah SMP Negeri 1 Barus yaitu 3 $M^{2}$ mencakup 14 ruang kelas, 1 laboratorium, 1 perpustakaan. Di kecamatan Barus salah satu yang terdampak pandemi covid-19 terutama pada dunia pendidikan yaitu SMP Negeri 1 Barus.

\section{Hasil Penelitian}

Penelitian dilaksanakan di kelas VII-B SMP Negeri Barus pada bulan Maret 2021. Sampel penelitian ini sebanyak 26 orang siswa. Pemberian angket dilakukan sebanyak 2 kali yaitu pemberian angket pertama pada tanggal 01 Maret 2021 dan pemberian angket kedua pada tanggal 08 Maret 2021. Pemberian angket ini bertujuan untuk mengetahui gambaran minat belajar matematis siswa selama pandemi covid-19. Berikut hasil jawaban angket yang dilakukan oleh siswa kelas VII-B SMP Negeri 1 Barus yang berjumlah 26 siswa.

Berdasarkan tabel diatas, dapat dijelaskan bahwa pada pemberian pertama angket kepada siswa bahwa jumlah nilai siswa adalah $1.179,63 \%$ dengan rata-rata 45,37\% yang terdiri dari 9 orang siswa dengan kategori cukup dengan jumlah nilai 279,81\%, 13 orang siswa dengan kategori sedang dengan jumlah nilai 626,52\%, 3 orang siswa dengan kategori baik dengan jumlah nilai 193,3\%, dan 1 orang dengan kategori sangat baik dengan jumlah nilai 80. Dengan demikian peneliti menyimpulkan bahwa minat belajar siswa selama pandemi covid-19 di SMP Negeri 1 Barus termasuk dalam kategori sedang.

\section{PEMBAHASAN}

Hasil penelitian yang disajikan dalam bentuk analisis minat belajar selama pandemi covid-19 siswa kelas VII SMP Negeri 1 Barus. Pada awal pemberian angket pada mingu pertama kepada siswa kelas VII-B SMP negeri 1 Barus memiliki minat belajar yang masuk dalam kategori sedang dengan ratrata $45,37 \%$ dan pada minggu kedua menunjukkan adanya peningkatan pada minat belajar matematika siswa dengan rata-rata 63,56\% masuk dalam kategori baik. Berikut hasil angket minat belajar siswa pada minggu pertama dan kedua yang akan disajikan dalam bentuk tabel. 
Tabel 3

Hasil Angket Minat Belajar Siswa Selama Pandemi Covid-19 Kelas VII-B SMP Negeri 1 Barus Pada Minggu Pertama

\begin{tabular}{|c|c|c|c|c|}
\hline \multirow[t]{2}{*}{ No } & \multirow[t]{2}{*}{ Skor } & \multirow[t]{2}{*}{ Kategori } & \multirow[t]{2}{*}{$\begin{array}{l}\text { Jumlah } \\
\text { sampel }\end{array}$} & $\begin{array}{c}\text { Jumlah Skor Yang } \\
\text { Diperoleh } \times 100 \%\end{array}$ \\
\hline & & & & Jumlah Skor Maksimal \\
\hline 1 & $0-19,99 \%$ & Kurang & 0 & 0 \\
\hline 2 & $20,99 \%-39,99 \%$ & Cukup & 9 & $34,61 \%$ \\
\hline 3 & $40,99 \%-59,99 \%$ & Sedang & 13 & $50 \%$ \\
\hline 4 & $60,99 \%-79,99 \%$ & Baik & 3 & $11,54 \%$ \\
\hline 5 & $80,99 \%-100 \%$ & Sangat Baik & 1 & $3,85 \%$ \\
\hline & Jumlah & & 26 & 100 \\
\hline
\end{tabular}

Tabel 4

Hasil Angket Minat Belajar Siswa Selama Pandemi Covid-19 Kelas VII-B SMP Negeri 1 Barus Pada Minggu Kedua

\begin{tabular}{|c|c|c|c|c|}
\hline No & Skor & Kategori & $\begin{array}{l}\text { Jumlah } \\
\text { sampel }\end{array}$ & $\begin{array}{c}\text { Jumlah Skor Yang } \\
\text { Diperoleh } \times 100 \%\end{array}$ \\
\hline
\end{tabular}

$\begin{array}{rr}1 & 0-19,99 \% \\ 2 & 20,99 \%-39,99 \% \\ 3 & 40,99 \%-59,99 \% \\ 4 & 60,99 \%-79,99 \% \\ 5 & 80,99 \%-100 \% \\ & \text { Jumlah }\end{array}$

Kurang
Cukup
Sedang
Baik
Sangat Baik

Jumlah Skor Maksimal

Berdasarkan tabel hasil minat belajar siswa selama pandemi covid-19 yang diberikan pada 26 sampel penelitian di minggu kedua menunjukkan bahwa minat belajar siswa berada pada kategori baik sebanyak 14 orang siswa atau 53,84\% siswa disebabkan oleh siswa selalu semangat dan rajin dalam belajar maupun mengerjakan tugas dirumah, siswa selalu berusaha mengerjakan soal matematika dengan sungguh-sungguh, ketika diberi tugas siswa langsung mengerjakannya, jika ada soal yang tidak bisa dikerjakan maka siswa akan bertanya kepada orang lain, suasana yang nyaman yang dapat menambah minat belajar siswa, siswa juga mengerjakan tugas matematika jika disuruh guru, ketika diberi soal matematika siswa merasa bisa mengerjakannya, serta siswa mudah memahami materi yang diberikan guru. $3,85 \%$ berada pada kategori cukup sebanyak 1 orang siswa disebabkan oleh siswa rajin mengerjakan tugas-tugas dirumah, ketika diberi tugas siswa langsung mengerjakannya, jika ada soal yang tidak bisa siswa kerjakan maka siswa akan bertanya kepada orang lain, siswa juga mengerjakan tugas matematika jika disuruh guru, serta siswa mudah memahami materi yang diberikan oleh guru. 26,92\% berada pada kategori sedang sebanyak 7 orang siswa siswa disebabkan oleh siswa selalu semangat dan rajin dalam belajar maupun mengerjakan tugas dirumah, ketika diberi tugas siswa langsung mengerjakannya, jika ada soal yang tidak bias dikerjakan maka siswa akan bertanya akan kepada orang lain, suasan yang nyaman dapat menambah minat belajar siswa, siswa juga mengerjakan tugas matematika jika disuruh guru, serta siswa juga mudah memahami materi yang diberikan oleh guru, dan $15,39 \%$ berada pada kategori sangat baik sebanyak 4 orang siswa disebabkan oleh siswa merasa pelajaran matematika merupakan pelajaran favorit, siswa rajin dan semangat dalam belajar matematika dirumah, siswa juga tidak mudah bosan ketika belajar matematika dirumah, siswa selalu berusaha mengerjakan soal-soal matematika dirumah, ketika diberi tugas siswa langsung mengerjakannya, jika ada soal yang tidak bias dikerjakan maka siswa akan bertanya kepada orang lain, suasana yang nyaman dapat menambah minat belajar siswa, siswa juga sering mengulang-ulang pelajaran matematika dirumah. Ketika diberi soal matematika, siswa merasa bisa mengerjakannya serta siswa juga mudah memahami materi yang diberikan oleh guru. 


\section{KESIMPULAN}

Berdasarkan uraian pada bab sebelumnya, maka penulis mengemukakan kesimpulan bahwa minat belajar siswa selama pandemi covid-19 di SMP Negeri 1 Barus tergolong sedang pada minggu pertama penelitian menunjukkan bahwa minat belajar siswa berada pada kategori sedang sebanyak 13 orang siswa atau 50\% siswa disebabkan oleh siswa selalu semangat dan rajin dalam belajar maupun mengerjakan tugas dirumah, ketika diberi tugas siswa langsung mengerjakannya, jika ada soal yant tidak bias dikerjakan maka siswa akan bertanya akan kepada orang lain, suasana yang nyaman dapat menambah minat belajar siswa, siswa juga mengerjakan tugas matematika jika disuruh guru, serta siswa juga mudah memahami materi yang diberikan oleh guru. 34,61\% berada pada kategori cukup sebanyak 9 orang siswa.11,54\% berada pada kategori baik sebanyak 3 orang siswa, dan 3,85\% berada pada kategori sangat baik sebanyak 1 orang siswa.

Pada minggu kedua menunjukkan peningkatan pada minat belajar siswa menunjukkan bahwa minat belajar siswa berada pada kategori baik sebanyak 14 orang siswa atau $53,84 \%$ siswa disebabkan oleh siswa selalu semangat dan rajin dalam belajar maupun mengerjakan tugas dirumah, siswa selalu berusaha mengerjakan soal matematika dengan sungguh-sungguh, ketika diberi tugas siswa langsung mengerjakannya, jika ada soal yant tidak bisa dikerjakan maka siswa akan bertanya akan kepada orang lain, suasana yang nyaman yang dapat menambah minat belajar siswa, siswa juga mengerjakan tugas matematika jika disuruh guru, ketika diberi soal matematika siswa merasa bisa mengerjakannya, serta siswa mudah memahami materi yang diberikan guru. 3,85\% berada pada kategori cukup sebanyak 1 orang siswa. $26,92 \%$ berada pada kategori sedang sebanyak 7 orang siswa siswa, dan $15,39 \%$ berada pada kategori sangat baik sebanyak 4 orang siswa

\section{IMPLIKASI}

Implikasi merupakan arah dan tindak lanjut dari makna yang terkandung dalam temuan penelitian. Dengan demikian penelitian ini memiliki implikasi terdapat minat belajar matematika siswa selama pandemi covid-19 di SMP Negeri 1 Barus masuk dalam kriteria baik, oleh karena itu agar kedepannya siswa lebih memfokuskan dan lebih meningkatkan minat belajar matematika selama pandemi covid-19 guna menghasilkan generasi berprestasi dan membanggakan.

\section{SARAN}

Adapun saran dalam penelitian ini adalah sebagai berikut:

1. Bagi siswa, diharapkan untuk lebih meningkatkan lagi minatnya dalam belajar sehingga dapat meraih prestasi yang diharapkan dan membanggakan kedua orang tua.

2. Bagi guru, supaya selalu membantu dalam meningkatkan minat belajar siswa. Dalam belajar guru diharapkan dalam menyampaikan pelajaran harus mampu membuat siswa senang dalam belajar.

3. Bagi penelitian selanjutnya, sebagai bahan masukan dalam membuat karya ilmiah yang lebih baik lagi.

\section{DAFTAR PUSTAKA}

Arikunto, Suharsimi. 2014. Prosedur Penelitian, Suatu Pendekatan Praktik. Jakarta: Rineka Cipta.

Astuti, Siwi Puji. 2015. Pengaruh Kemampuan Awal Dan Minat Belajar Terhadap Prestasi Belajar Fisika. Formatif: Jurnal Ilmiah Pendidikan MIPA. Volume V Tahun 2020.

Fauziah Amni, dkk. 2017 Hubungan Antara Motivasi Belajar Dengan Minat Belajar Siswa Kelas IV SDN Poris Gaga 05 Kota Tangerang. Jurnal JPSD. Volume IV Tahun 2021.

Fitriani, Yani.dkk. 2020. Motivasi Belajar Mahasiswa Pada Pembelajaran Daring Selama Pandemi Covid19. Jurnal Kependidikan: Jurnal Hasil Penelitian Dan Kajian Kepustakaan. Volume VI Tahun 2020.

Lestari, Indah. 2015 Pengaruh Waktu Belajar Dan Minat Belajar Terhadap Hasil Belajar Matematika. Jurnal Formatif. Volume III Tahun 2020.

Nurhafifah, Astri Yuliani dan Maya sari. 2019. Analisis Minat Belajar Siswa Terhadap Pembelajaran Matemtika Pada Siswa SMA Di Kabupaten Bandung Barat. Journal On Education. Volume I Tahun 2020.

Nurhasanah Siti dan Sobandi A. 2016. Minat Belajar Sebagai Determinan Hasil Belajar Siswa. Jurnal Pendidikan Manajemen Perkantoran. Volume I. Tahun 2020.

Nurkholis. 2020. Dampak Pandemi Novel-Corona Virus Disiase (Covid-19) Terhadap Psikologi Dan Pendidikan Serta Kebijakan Pemerintah. Jurnal PGSD. Volume V Tahun 2020. 
ISSN. 2621-9832

JURNAL MathEdu (Mathematic Education Journal) http://journal.ipts.ac.id/index.php/MathEdu Vol. 4. No. 3 November 2021

Rachmawati Febri, Sojanah janah. 2019. Pengaruh Media Pembelajaran Dan Komunikasi Interpersonal Guru Terhadap Minat belajar Siswa Pada Mata Pelajaran Kearsipan Di SMKN 1 Bandung. Jurnal Pendidikan Manajemen Perkantoran. Volume IV Tahun 2020.

Rangkuti, Ahmad Nizar. 2014. METODE PENELITIAN PENDIDIKAN Pendekatan Kuantitatif, Kualitatif, PTK, Dan Penelitian Pengembangan. Bandung: Citapustaka Media.

Setiawan, Adib Rifgi. 2020. Lembar Kegiatan Literasi Saintifik Untuk Pembelajaran Jarak Jauh Topik Penyakit Coronavirus 2019 (COVID-19). Jurnal Edukatif: Jurnal Ilmu Pendidikan. Volume II Tahun 2020.

Simbolon, Naeklan. 2014. Faktor-Faktor Yang Mempengaruhi Minat Belajar Peserta Didik. Fakultas Ilmu Pendidikan Unimed. Volume I Tahun 2020.

Sugiyono. 2014. METTODE PENELITIAN PENDIDIKAN (Pendekatan Kuantitatif, Kualitatif, Dan $R \& D)$. Bandung: Alfabeta

Sugiyono. 2018. METTODE PENELITIAN PENDIDIKAN (Pendekatan Kuantitatif, Kualitatif, Dan $R \& D)$. Bandung: Alfabeta.

Yunus, Nur Rhim dan Rezli, Annissa. 2020. Kebijakan Pemberlakuan Lockdown Sebagai Antisipasi Penyebaran Corona Virus Covid-19. Jurnal Sosial Dan Budaya Syar-i. Volume VII Tahun 2020 . 